50. Schneerson, R., Bradshaw, M. W., Whisnant, J. K., Parke, J. C., Jr., and Robbins, J. B.: An Escherichia coli antigen cross-reactive with the capsular polysaccharide of Haemophilus influenzae type b: Occurrence among known serotypes and immunochemical and biologic properties of $E$. coli antisera towards $H$. influenzae type b. J. Immunol., 108: 1551 (1972).

51. Smith, R. T., and Eitzman, D. V.: The development of the immune response. Pediatrics, 65: 165 (1964).

52. Smith. T. E., and Bryant, G.: Studies on pathogenic E. coli from bovine sources. J. Exp. Med., 46: 155 (1927).

53. Sterzl, J., Mandel, L., Miler, l., and Riha, I.: Development of immune reactivity in the absence of an antigenic stimulus. In: Molecular Basis of Antibody Formation, p. 351 (Czechoslovakia Academy of Sciences, Academic Press, New York, 1965).

54. Stirm, S., Drskov, F., Drskov, I., and Mansa, B.: Episome-carried surface antigen K88 of Escherichia coli. II. Isolation and chemical analysis. J. Bacteriol., 93: 731 (1967).

55. Stites, D. P.. Wybran, J. Carr, M., and Fudenberg, H. H.: Development of cellular competence in man, In: Ontogeny of Active Immunity, p. 113 (Ciba Foundation Symposium, 1972).

56. Stossel, T. P., Alper, C. A., and Rosen, F. S.: Opsonic activity in the newborn:
Roles of properdin. Pediatrics, 52: 134 (1973)

57. Watson, D. G.: Purulent neonatal meningitis: A study of forty-five cases. J. Pediat., 50: 352 (1957)

58. Wilson, D., Whisnant, J. K., Halterman, H., and Robbins, J. B.: PR P capsular antigen in Haemophilus influenzae type b meningitis: correlation with antibody formation and clinical outcome. (Thirteenth ICAC Proceedings, 1973).

59. Wolberg. G.. and deWitt, D.: Mouse virulence of K (L) antigen-containing st rains of Escherichia coli. J. Bacteriol., 100: 730 (1969).

60. Wyle. F. A., Artensetin. M. S., Brandt. B. L., Tramont, E. C., Kasper. D. L. Altieri, P. L., Berman, S. L., and Lowenthal, J. P.: Immunologic response of man to Group B meningococcal polysaccharide vaccines J. Infect. Dis., 126: 514 (1972).

61. Yurchak, A. M., and Austrian, R.: Serologic and genetic relationships between pneumococci and other respiratory streptococci. Trans. Ass. Amer. Phys., 89: 368 (1966).

62. Requests for reprints should be addressed to: J. B. Robbins, M. D., Division of Bacterial Products, Bureau of Biologics, 8800 Rockville Pike, Bethesda, Md 20014 (USA).

63. Accepted for publication September 16. 1975.
Cystic fibrosis genetic disease isoelectric focusing $\alpha$-2-macroglobulin protease inhibition

\title{
Studies on Cystic Fibrosis Using Isoelectric Focusing. II. Demonstration of Deficient Proteolytic Cleavage of $\alpha_{2}$-Macroglobulin in Cystic Fibrosis Plasma
}

\author{
GREGORY B. WILSON'61: AND H. HUGH FUDENBERG \\ Section of Immunology. Department of Medicine, University of California, San Francisco, California, and \\ Department of Clinical Immunology and Microbiology, Medical University of South Carolina. Charleston, South \\ Carolina, USA
}

\section{Extract}

A protein with an isoelectric point ( $\mathrm{pI}$ ) of 5.48 was found to be deficient in plasma from most cystic fibrosis ( $C F$ ) homozygotes and obligate heterozygote carriers for $C F$ as compared with normal control plasma. Purification of the protein with a $\mathrm{pl}$ of 5.48 from normal plasma was performed using ammonium sulfate precipitation, DEAE-cellulose and CM-cellulose chromatography, Sephadex G-200 gel filtration, starch block electrophoresis, and Sepharose 4B gel filtration. The purified protein migrated as a single band on polyacrylamide gel electrophoresis, and displayed a single arc on immunoelectrophoresis against polyvalent antiserum to whole human serum. Results from various techniques used in its characterization indicate that this protein is a fragment of $\alpha_{2}$-macroglobulin $\left(\alpha_{2} M\right)$ which is derived from $\alpha_{2} M$ by proteolytic cleavage of intact $\alpha_{2} M$ subunits. Quantitation of $\alpha_{2} M$ levels in plasma indicated no significant differences between levels of $\alpha_{2} M$ in $C F$ homozygote, obligate heterozygote carrier, or normal control plasma samples. Quantitation of arginine esterase activity in plasma treated with chloroform and ellagic acid indicated that both the total arginine esterase activity and that fraction of arginine esterase activity inhibited by soybean trypsin inhibitor (SBTI) were decreased in most CF homozygote and obligate heterozygote plasma samples relative to normal control values. The results of this study indicate that plasma samples from $\mathrm{CF}$ homozygotes and obligate heterozygote carriers for $\mathrm{CF}$ show deficient proteolytic cleavage of $\alpha_{2} \mathrm{M}$ as compared with normal control plasma, and suggest that a structural abnormality in $\alpha_{2} \mathrm{M}$ or a deficiency in plasma proteolytic activity may be responsible for this deficiency in proteolysis.

\section{Speculation}

An abnormality in the binding affinity of $\alpha_{2} M$ for plasma proteases may account for the presence of "factors" in CF homozygotes and obligate heterozygote carriers.

Cystic fibrosis is a generalized metabolic disorder. resulting from an unknown genetic defect (33). It is generally thought to be transmitted as a single autosomal recessive trait $(10,33)$, although several authors have found evidence for genetic heterogeneity within the clinical entity known as $\mathrm{CF}(38.53)$ and have suggested that the disease may actually be a group of closely related genctio abnormalities with similar pathologic consequences (53). Several reports have indicated that sera from patients with CF (CF homozygotes) and from obligate heterozygote carricrs contain factors that may be characteristic of the disease and thus possibly related to the primary genetic defect in $\mathrm{CF}(7,11,50.52 .53)$. Other lactors are found in saliva and sweat from CF homozygotes (31) and have been produced from cultured cells derived from $C F$ homozygotes and heterozygotes $(46,13)$. Partial characterization of the various CF factors suggests that they are closely related 
structurally and functionally; generally they are small cationic proteins (molecular weight $1,000-10,000$ ) that can bind or complex to immunoglobulin $\mathrm{G}(1,2,4,5,13,50,51)$.

Recently. Hirschhorn (22) and Conover et al. (13) presented evidence that the CF factor(s) may be a C3a (anaphylatoxin) or a kinin-like molecule (12), and they hypothesized that the primary defect in CF may be related to a quantitative or qualitative deficiency in anaphylatoxin inhibitor (AI), an enzyme similar to carboxypeptidase B (13). Although the possible identification of the CF factor(s) such as C3a has been questioned $(1,28)$, abnormalities in both complement-mediated cytotoxicity $(51)$ and plasma kallikrein or arginine esterase activity (38. 39) have been reported for $C F$ homozygotes and heterozygotes. In a previous study (52) we showed that sera from CF homozygotes and obligate heterozygote carriers are deficient in a protein of the $\beta$-globulin fraction, and we speculated that the deficiency might be responsible for the accumulation of CF factor in serum $(48,52)$. We now report available evidence that this protein is a proteolytic derivative (fragment) of $\alpha_{2}$-macroglobulin $\left(\alpha_{2} \mathrm{M}\right)$, a major inhibitor of kallikrein, plasmin, and similar plasma arginine esterases $(20,21,24)$. The relationship of our findings to those of Conover et al. (13), Rao et al. $(38,39)$, and others suggests a possible mechanism for the pathophysiology of CF.

\section{MATERIALS AND METHODS}

\section{CHEMICALS}

All chemicals used were reagent grade unless otherwise indicated. Benzoyl- $D L$-arginine- $p$-nitroanilide (BAPNA), tosyl arginine methylester (TAME), trypsin three times crystallized (type III), soybean trypsin inhibitor (SBTI) (type I-s), ethylenediaminetetraacetic acid (EDTA), ellagic acid (practical grade), and sodium dodecyl sulfate (SDS) were obtained from Sigma Chemical Co., St. Louis, Mo. Dithiothreitol (DTT) was from Calbiochem, San Diego, Calif. Kaolin was from Allied Chemical Co., Morristown, N. J. DEAE-cellulose and CM-cellulose ion exchange resins (DE-52 and CM-52) were from Whatman. Sephadex G-200 and Sepharose 4B were from Pharmacia Fine Chemicals, Inc., Piscataway, N. J. Purified $\alpha_{2}$-macroglobulin $(1 \mathrm{mg}$ ) used for comparative purposes was a gift from Mrs. Helga Johnson.

\section{ANTISERA}

Antisera to human $\alpha_{2}$-macroglobulin, plasminogen, and haptoglobin were obtained from Behring Diagnostics, Woodbury, N. Y. Antisera to human albumin, IgM, C3, and whole serum were from Meloy Laboratories, Springfield, Va.

\section{PLASMA}

Venous blood from normal individuals and from CF patients and parents (obligate heterozygote carriers) was collected in plastic syringes or plastic transfer packs and mixed into 1:9 volume of $3.8 \%(\mathrm{w} / \mathrm{v})$ sodium citrate in polypropylene tubes. Plasma was separated by centrifugation at $2,000 \times g$ for $10 \mathrm{~min}$ at $4^{\circ}(20)$ and frozen in aliquots in polypropylene at $-70^{\circ}$. The plasma was thawed only once for use.

Informed consent was obtained from each subject (or in the case of minors, from their parents) before collection of the plasma.

\section{ELECTROPHORESIS}

Immunoelectrophoresis (IEP), counterimmunoelectrophoresis (CIE), and double immunodiffusion were performed by established methods (37). Quantitation of $\alpha_{2} \mathrm{M}$ in whole blood and in various fractions (37) was performed by radial immunodiffusion (54).

For analytic acrylamide gel electrophoresis, an apparatus similar in construction to that described by Raymond (42), was used, with a gel concentration of $4 \%$ and with Tris $\cdot \mathrm{HCl}$ glycine buffer, pH 8.9 (14).
Starch block electrophoresis was performed by slight modification of the methods of Kunkel and Trautman (25) and McConnell (34), with the electrophoresis conducted at $300 \mathrm{~V}$ for $14 \mathrm{hr}$ using

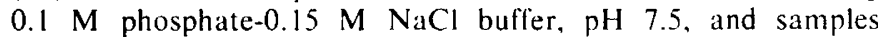
int roduced into a block $1.5 \times 10 \times 47 \mathrm{~cm}, 10 \mathrm{~cm}$ from the cathodal end. At the completion of a run, each $1-\mathrm{cm}$ section was eluted three times with $20 \mathrm{ml} 0.01 \mathrm{M}$ phosphate- $0.15 \mathrm{M} \mathrm{NaCl}$ buffer, $\mathrm{pH} 8.0$. After clarification by centrifugation $\left(2,000 \times \mathrm{g}, 15 \mathrm{~min}, 4^{\circ}\right)$ the eluates were concentrated in an Amicon ultrafiltration cell equipped with an XM50 membrane (55).

\section{ELECTROFOCUSING}

Isoelectric focusing in thin layer polyacrylamide gels with $4 \mathrm{M}$ urea added was performed as described previously (52). except that only gradients of $\mathrm{pH} 3.8$ were used. A linear gradient (Fig. 1) was constructed by mixing pH $2.54,3.55,4-6$, and 5-8 Ampholine carrier ampholytes (56) to obtain a final concentration of $2.1 \%$ $(\mathrm{w} / \mathrm{v})$. Electrofocusing was conducted at $500 \mathrm{~V}$ for $18 \mathrm{hr}$. Isoelectric focusing was used throughout the investigation to follow the isolations of the $\alpha_{2} \mathrm{M}$ subunits and fragments with pl's at and near $\mathrm{pH} 5.48$, to analyze whole plasma samples subjected to various treatments, and to assess the conversion of $\alpha_{2} \mathrm{M}$ to its subunits (mol wt 185,000) and fragments (mol wt 85,000) (21).

\section{ENZYMATIC REACTIONS}

For measurement of total plasma arginine esterase activity. Hageman factor was activated with chloroform and $0.05 \mathrm{mM}$ ellagic acid in $0.1 \mathrm{M}$ phosphate- $0.15 \mathrm{M} \mathrm{NaCl}$ buffer (phosphate saline), pH 7.5, exactly as described by Rao al et. (39). Arginine esterase activity was assayed with TAME as substrate $(0.015 \mathrm{M})$ in phosphate saline $(\mathrm{pH} 7.6)$ according to the methods of Siegelman et al. (45). Activity was measured in the presence and absence of $\mathrm{SBTl}$ at $400 \mu \mathrm{g} / \mathrm{ml}(38,39)$ in phosphate saline, $\mathrm{pH} 7.6$.

For isoelectric focusing, Hageman factor was activated either by incubation of whole plasma in glass at $4^{\circ}$ for $2 \mathrm{hr}$ (32) or by treatment with kaolin $\left(10 \mathrm{mg} / \mathrm{ml}\right.$ plasma, $\left.15 \mathrm{~min}, 25^{\circ}\right)(9,20)$ or ellagic acid (without prior treatment with chloroform).

In experiments employing trypsin to convert purified $\alpha_{2} \mathrm{M}$ to its proteolytic derivatives $(21)$, the specific activity of trypsin preparations was experimentally determined by titration with SBTI following the methods of Ganrot $(16,17)$ and Harpel $(21)$ with BAPNA as substrate. Esterolytic activity of trypsin preparations was determined by the method of Siegelman et al. (45) with trypsin in $0.05 \mathrm{M} \mathrm{CaCl}_{2}$ and TAME as substrate.

The functional capacities of different $\alpha_{2} \mathrm{M}$ preparations were assessed by determining the esterolytic activity associated with $\alpha_{2} \mathrm{M}$ with and without trypsin added at different molar ratios (21) before and after the addition of SBTI $(16,18,21)$. Trypsin was

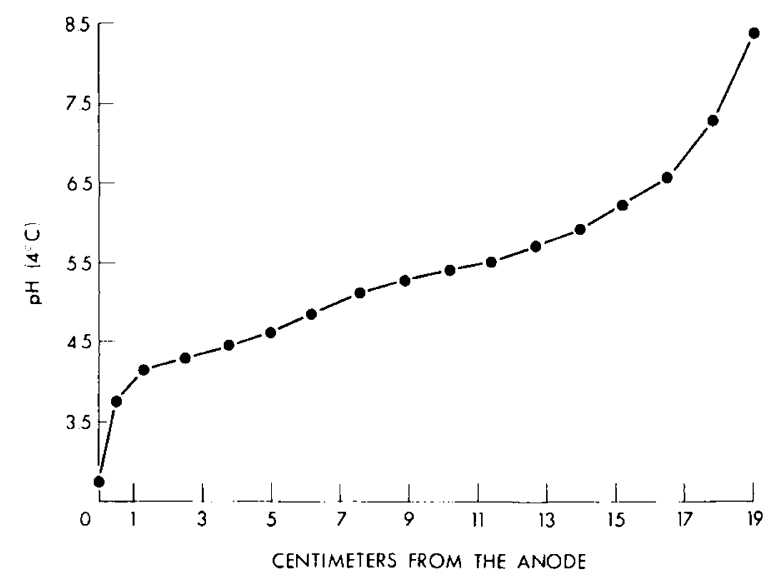

Fig. 1. Result of $\mathrm{pH}$ measurement at $4^{\circ}$ from anode to cathode on the surface of a $5 \%$ polyacrylamide gel containing $2.1 \%(\mathrm{w} / \mathrm{v})$ Ampholine carrier ampholytes, pH 3-8, $4 \mathrm{M}$ urea. 
incubated with $\alpha_{2} \mathrm{M}$ for $30 \mathrm{~min}$ at $37^{\circ}$ in phosphate saline ( $\mathrm{pH} \mathrm{8.0)}$ before the addition of SBTI $(400 \mu \mathrm{g} / \mathrm{ml})$.

The functional states of purified $\alpha_{2} \mathrm{M}$ preparations of $\alpha_{2} \mathrm{M}$ treated with trypsin were also determined by SDS-polyacrylamide gel electrophoresis, with or without prior reduction with DTT, as described by Harpel (2l), except that $\alpha_{2} \mathrm{M}$ and $\alpha_{2} \mathrm{M}$-trypsin mixtures were incubated in phosphate saline $(\mathrm{pH} \mathrm{8.0)}$ ) and electrophoresis was conducted in a 5\% slab gel using Tris-acetate-EDTA buffer, pH 7.4 (15) and an apparatus similar to that of Raymond (42). Molecular weight markers included human serum albumin in reduced form $(68,000)$ and purified $\alpha_{2} \mathrm{M}$ in reduced (approximately 85,000 ) and nonreduced (approximately 340,000) form (21).

\section{PURIFICATION OF $\alpha_{2} \mathrm{M}$ AND $\alpha_{2} \mathrm{M}$ FRAGMENTS OBSERVED BY ISOELECTRIC FOCUSING $\left(\alpha_{2} \mathrm{M}_{\mathrm{r}}\right)$}

All isolation procedures were performed at $4^{\circ}$ using plastic or siliconized labware. Protein concentrations of preparations were determined by the method of Lowry et al. (30) with bovine serum albumin as standard. Protein concentrations of column eluates were estimated by recording their absorbance at $280 \mathrm{~nm}$. Fractions were concentrated in Amicon stirred ultrafiltration cells of 50 or 10 $\mathrm{ml}$ capacity equipped with an XM50 membrane (55). Protein compositions of individual fractions or purified products were assessed by IEP, CIE, and double immunodiffusion with specific antisera where indicated. All isolation procedures were repeated a minimum of three times.

ISOLATION OF $\alpha_{2}$ M FRAGMENTS OBSERVABLE BY ISOELECTRIC FOCUSING $\left(\alpha_{2} \mathrm{M}_{f}\right)$

Chilled plasma (100--200 ml) was brought to $25 \%$ saturation by the addition of saturated ammonium sulfate $\left(100 \%, 4^{\circ}\right)$ while stirring. After $30 \mathrm{~min}$ the mixture was centrifuged $(12,000 \times g, 30$ $\min )$ : the supernatant was then removed and brought to $50 \%$ saturation with saturated ammonium sulfate, stirred for $30 \mathrm{~min}$, and the precipitate was harvested by centrifugation $(12,000 \times g, 30$ $\mathrm{min})$. The precipitate was resuspended in $0.1 \mathrm{M}$ phosphate- $0.15 \mathrm{M}$ $\mathrm{NaCl}$ buffer, $\mathrm{pH} 8.0$, and dialyzed exhaustively against $0.01 \mathrm{M}$ phosphate buffer, $\mathrm{pH} 8.0$, in preparation for chromatography. A concentrated preparation of the $50 \%$ precipitated proteins $(100$ $\mathrm{mg} / \mathrm{ml})$ was then applied to a DEAE-cellulose column $(3.0 \times 45$ $\mathrm{cm}$ ) previously equilibrated with $0.01 \mathrm{M}$ phosphate, $\mathrm{pH} 8.0$. Fractionation was performed with a continuous sodium chloride gradient $(0.00-0.2 \mathrm{M} \mathrm{NaCl})$ or a discontinuous gradient (in consecutive steps) by elution with $300 \mathrm{ml}$ volume of $0.01 \mathrm{M}$ phosphate plus either $0.00 \mathrm{M}, 0.05 \mathrm{M}, 0.1 \mathrm{M}$, or $0.2 \mathrm{M} \mathrm{NaCl}$.

Fractions containing $\alpha_{2} \mathrm{M}_{\mathrm{r}}$ were then dialyzed against $0.02 \mathrm{M}$ sodium acetate- $0.05 \mathrm{M} \mathrm{NaCl}$ buffer, $\mathrm{pH} 5.0$, concentrated to 30 $\mathrm{mg} / \mathrm{ml}$, and fractionated on a CM-cellulose column $(2.2 \times 40 \mathrm{~cm})$ previously equilibrated with $0.02 \mathrm{M}$ sodium acetate buffer, pH 5.0. After washing the column with $250 \mathrm{ml}$ of $0.02 \mathrm{M}$ sodium acetate- $0.05 \mathrm{M} \mathrm{NaCl}$ buffer ( $\mathrm{pH} 5.0$ ), the fraction that contained $\alpha_{2} \mathrm{M}_{\mathrm{f}}$ was eluted with $0.02 \mathrm{M}$ sodium acetate $0.15 \mathrm{M} \mathrm{NaCl}, \mathrm{pH}$ 5.0. The $0.15 \mathrm{M} \mathrm{NaCl}$ eluate was concentrated to $8 \mathrm{mg} / \mathrm{ml}$ and applied as separate 3.0-ml aliquots to a calibrated Sephadex G-200 column. Elution was performed in $0.01 \mathrm{M}$ phosphate- $0.15 \mathrm{M} \mathrm{NaCl}$ buffer, $\mathrm{pH}$ 8.0. Individual fractions containing $\alpha_{2} \mathrm{M}_{\mathrm{f}}$ from separate G-200 colums were pooled, concentrated, and subjected to starch block electrophoresis. Fractions containing $\alpha_{2} M_{r}$ obtained from starch block electrophoresis were further purified over a calibrated Sepharose $4 B$ column $(2.2 \times 100 \mathrm{~cm})$ using $0.01 \mathrm{M}$ phosphate -0.15 $\mathrm{M} \mathrm{NaCl}, \mathrm{pH}$ 8.0. Final preparations of $\alpha_{2} \mathrm{M}_{\mathrm{r}}$ had average TAME esterase activity levels of $1.2 \mu \mathrm{mol}$ TAME hydrolyzed $/ \mathrm{min} / \mathrm{mg}$ $\alpha_{2} M_{\mathrm{f}}(21,45)$. The Sephadex G-200 and Sepharose 4B columns were calibrated with blue dextran (mol wt 2,000,000; Pharmacia), IgM (mol wt 820,000), IgG (mol wt 150,000), human serum albumin (mol wt 68,000), and chymotrypsinogen A (mol wt 25,000; Pharmacia) as indicated.
ISOLATION OF $\alpha_{2} \mathrm{M}$

Purified $\alpha_{2} \mathrm{M}$ was obtained by the following procedure, adapted from Harpel (21) and McConnell (34). Whole plasma was mixed with SBTI $(0.2 \mathrm{mg} / \mathrm{ml})$ and EDTA $(10 \mathrm{mM})$ and dialyzed against $0.01 \mathrm{M}$ phosphate buffer, $\mathrm{pH} 8.0$, containing $10 \mathrm{mM}$ EDTA (phosphate EDTA). The whole plasma was then fractionated by DEAE-cellulose chromatography as described for $\alpha_{2} \mathbf{M}_{\mathrm{f}}$, except that the column was pre-equilibrated with phosphate EDTA and washed with $300 \mathrm{ml}$ phosphate EDTA and $0.05 \mathrm{M} \mathrm{NaCl}$ immediately after application of the plasma. The $\alpha_{2} \mathrm{M}$ fraction was then eluted with $300 \mathrm{ml} 0.1 \mathrm{M} \mathrm{NaCl}$, concentrated, and fractionated by Sephadex G-200 gel filtration, starch block electrophoresis, and Sepharose 4B gel filtration. Preparations of $\alpha_{2} \mathrm{M}$ found to be contaminated with haptoglobin or IgM were rerun on starch block electrophoresis and/or Sepharose 4B gel filtration. Purified preparations of $\alpha_{2} \mathrm{M}$ gave a single arc when analyzed by immunoelectrophoresis against potent polyvalent goat or rabbit anti-human serum. These preparations had low levels of spontaneous TAME esterase activity, averaging $0.10 \mu \mathrm{mol}$ TAME hydrolyzed $/ \mathrm{min} / \mathrm{mg}$ $\alpha_{2} \mathrm{M}(45)$.

\section{RESULTS}

\section{ANALYSIS OF WHOLE PLASMA BY ISOELECTRIC FOCUSING}

Twenty-five-microliter aliquots of freshly thawed plasma from $\mathrm{CF}$ homozygotes, obligate heterozygote carriers, and normal controls were analyzed by isoelectric focusing. Before activation, a protein band with a pl of 5.48 , which was observed previously in normal whole serum, was absent from all plasma samples. After activation in glass, however, a pattern qualitatively similar to that observed for serum was found in all normal controls but not in the majority of CF homozygote samples (Fig. 2, Table 1). Typical protein banding patterns for three normal and three CF homozygote plasma samples are shown in Figure 3. (The centimeter scale in Figures 2-4 correlates with the $\mathrm{pH}$ gradient in Figure 1.) Most activated CF plasma samples lacked band 1 (Table 1), and the majority were deficient in a second protein band (band 2) just
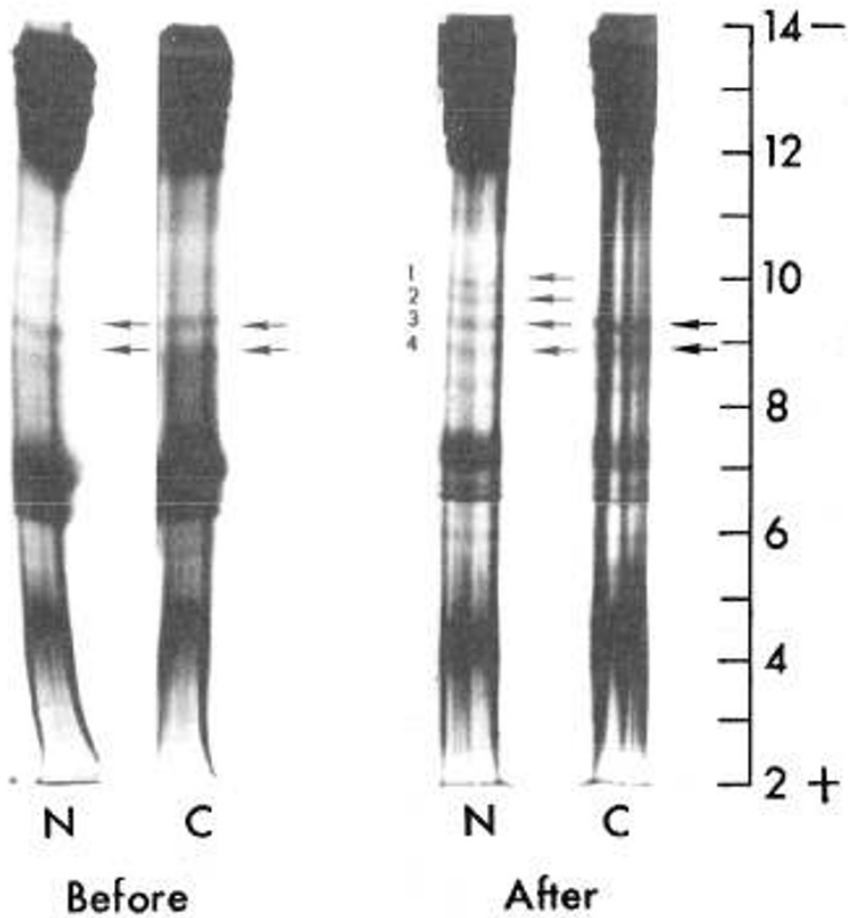

Fig. 2. Results of isoelectric focusing of $25 \mu \mathrm{l}$ whole plasma from a $\mathrm{CF}$ homozygote $(C)$ and normal control $(N)$ individual before and after activation of the plasma by glass. A centimeter scale shows the distance from the anode. 
Table 1. Relationship between $\alpha_{2}$-macroglobulin level, arginine esterase activity, and detection of $\alpha_{2}$-macroglobulin fragments in activated plasma

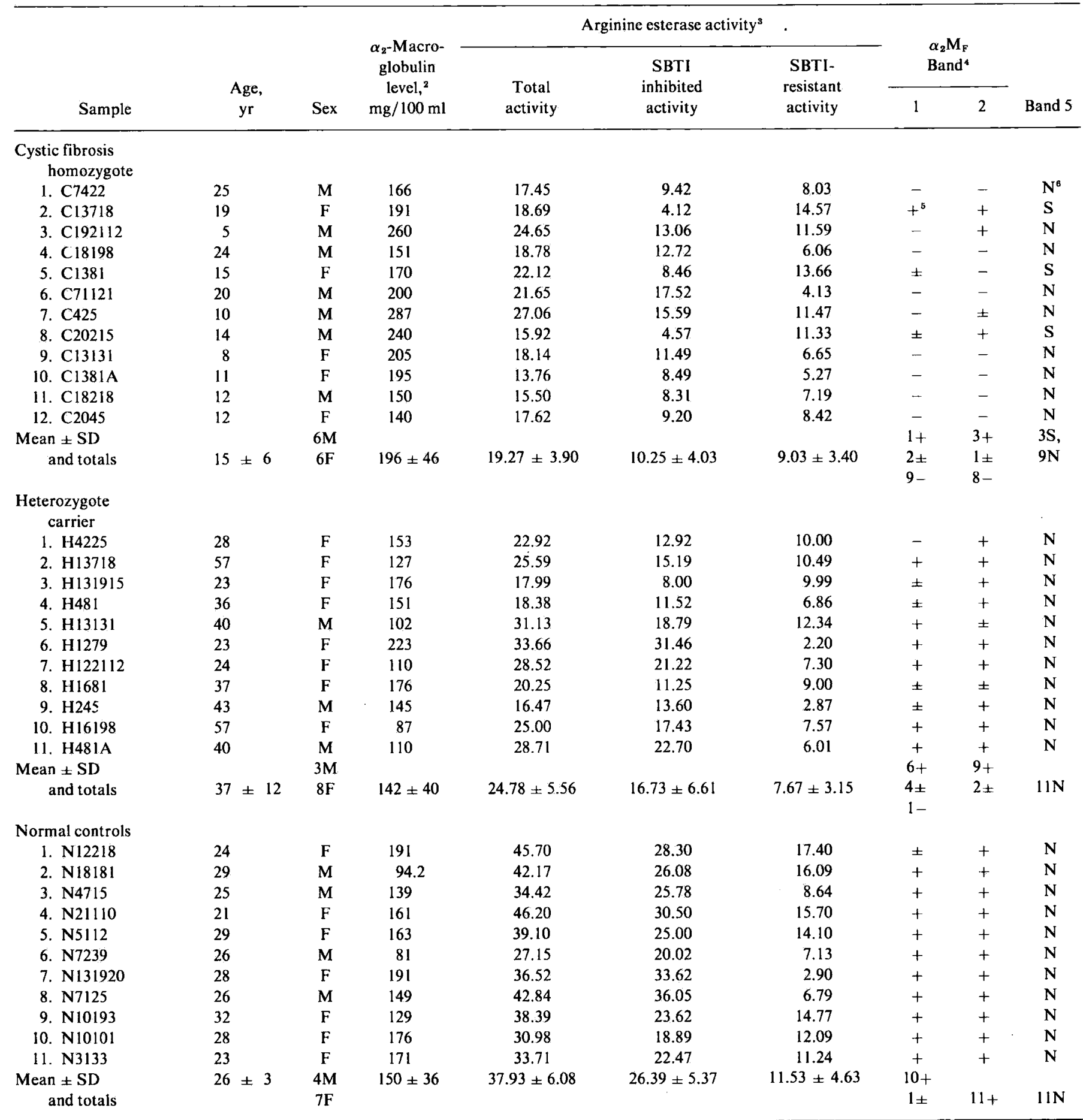

${ }^{1} \mathrm{M}$ : Male; F: Female; SBTI: soybean trypsin inhibitor; $\alpha_{2} \mathrm{M}_{\mathrm{F}}$ : fragment of $\alpha_{2}$-macroglobulin observed by isoelectric focusing.

${ }^{2}$ Measured by single radial immunodiffusion: values expressed to the nearest whole unit.

${ }^{3}$ Micromoles of tosyl arginine methyl ester hydrolyzed per hr per $\mathrm{ml}$ of plasma.

'Bands 1 and 2 as in Figures 3 and 4.

${ }^{\circ}+, \pm,-$ : bands 1 and 2 strong, faint and not present, respectively, when $25 \mu$ l of activated plasma was analyzed.

${ }^{6}$ Intensity of band 5 on isoelectric focusing. S: strong; N: normal.

below band 1 (Figs. 3 and 4, Table 1). CF plasma samples that were quantitatively normal for bands 1 and $2(+$ or \pm$)$, displayed a strong band (band 5) (Table 1, Fig. 3) with a pI of approximately 4.7 and an additional band just above it (arrow in Fig. 3), not found in normal controls. Obligate heterozygote carriers showed bands qualitatively similar to the normal controls, but band 1 was generally weaker (Table 1).
Bands 1 and 2 could be demonstrated only in glass-activated plasma. Since Hageman factor is known to be activated by glass and then in turn is involved in the activation of several other plasma proenzymes (i.e., plasminogen, plasminogen proactivator, prekallik rein) $(24,32,40)$, we used two other known activators of Hageman factor to determine whether bands 1 and 2 could be demonstrated in the CF samples that were negative after glass 


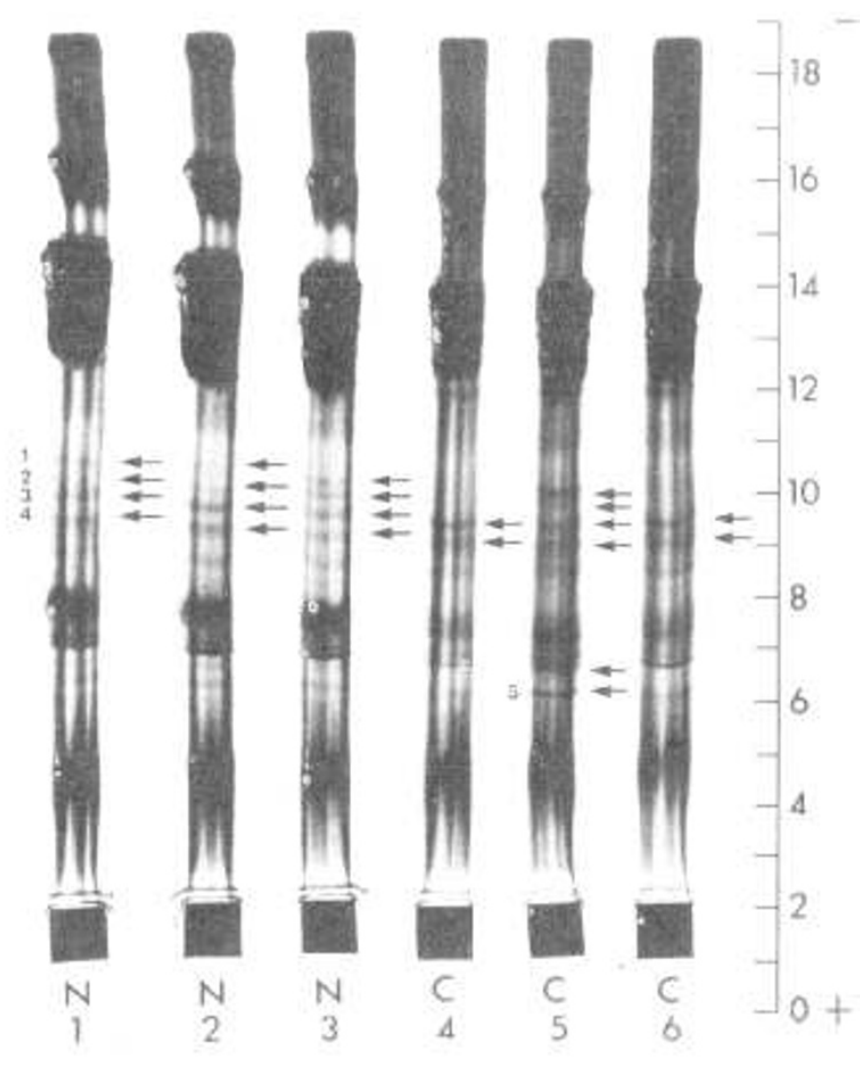

Fig. 3. Results of isoelectric focusing of $25 \mu$ l glass activated plasma from three normal control $(N)$ and three cystic fibrosis homozygote $(C)$ individuals. A centimeter scale shows the distance from the anode.

activation. Incubation with kaolin or ellagic acid gave results nearly identical to those for $C F$ and normal samples after glass activation.

\section{ISOLATION OF $\alpha_{2} \mathrm{M}$ AND ITS PROTEOLYTIC DERIVATIVES}

Protein band 1 (Fig. 4, sample $A$ ) was selectively concentrated from freshly thawed plasma by fractionating $100 \mathrm{ml}$ of normal plasma with $25 \%$ and then $50 \%\left(\mathrm{NH}_{4}\right)_{2} \mathrm{SO}_{4}$. The protein was shown to be in the $50 \%\left(\mathrm{NH}_{4}\right)_{2} \mathrm{SO}_{4}$ precipitate by electrofocusing (Fig. 4, sample B). Further fractionation of $1.0 \mathrm{~g}$ of the precipitated protein was carried out on a DEAE-cellulose column with a gradient of 0.00 to $0.2 \mathrm{M} \mathrm{NaCl}$ at constant pH (Fig. $5 A$ ). Subsequent analysis of the 11 fractions from the eluate showed that band 1 eluted in fractions VI and VII, corresponding to a $\mathrm{NaCl}$ concentration of 0.060 to $0.082 \mathrm{M}$. The results of isoelectric focusing of fraction VII are shown in Fig. 4, sample $C$. Results from DEAE-cellulose chromatography with discontinuous gradient elution showed that the $0.1 \mathrm{M} \mathrm{NaCl}$ eluate was the only fraction that contained this protein.

Further purification was accomplished by CM-cellulose chromatography using discontinuous gradient elution with $\mathrm{NaCl}$ at constant $\mathrm{pH}$. The protein band with a $\mathrm{pI}$ at 5.5 was found in the $0.15 \mathrm{M} \mathrm{NaCl}$ eluate (Fig. 4, sample $D$ ). Fractionation of the 0.15 M NaCl CM-cellulose eluate by Sephadex G-200 gel filtration yielded three peaks, corresponding to fractions with molecular weights greater than 250,000 (peak I), between 250,000 and 150,000 (peak II), and less than 150,000 (peak III) (Fig. 5B). Analysis of each peak by isoelectric focusing showed the band 1 protein in peak II (Fig. 4, sample E). Peak I contained approximately 3 times as much protein as peak II but showed no bands when analyzed by isoelectric focusing using $100 \mu \mathrm{l}$ of a $6 \mathrm{mg} / \mathrm{ml}$ solution. Analy.is of Sephadex G-200 peaks I and II by immunoelectrophoresis, however, indicated that they contained almost the same proteins. Peak I was composed predominantly of $\alpha_{2} \mathrm{M}$, haptoglobin, and IgM with trace amounts of C3; peak II contained $\alpha_{2} \mathrm{M}, \mathrm{C} 3$, and traces of haptoglobin and albumin (apparently in polymeric form).

Final purification was accomplished by starch block electrophoresis and Sepharose 4B gel filtration. The fraction containing protein band 1 was found in the fraction that eluted just after $\mathrm{IgM}$ (mol wt 820,000 ) (Fig. 5C). The final product displayed a single arc on immunoelectrophoresis against potent polyvalent rabbit or goat anti-human serum (Fig. 6 $\mathrm{A}$ ) and migrated as a single band on acrylamide gel electrophoresis at pH 8.9 (Fig. $6 B$ ). In tests against antisera to haptoglobin, IgM, C3, albumin, and $\alpha_{2} \mathrm{M}$, only anti- $\alpha_{2} \mathrm{M}$ showed a precipitation line when analyzed by immunoelectrophoresis, CIE, or double immunodiffusion. Isoelectric focusing, however, showed four closely spaced bands (Fig. 4, sample $F$ ), the uppermost band having a pl corresponding to band 1 of the whole activated plasma (Fig. 4, sample $A$ ).

\section{ANALYSIS OF $\alpha_{2} \mathrm{M}$ AND $\alpha_{2} \mathrm{M}_{\mathrm{t}}$ BY SDS-POLYACRYLAMIDE GEL ELECTROPHORESIS}

Since $\alpha_{2} M$ was found to represent bands 1 and 2, we next sought to explain why $\alpha_{2} \mathrm{M}$ in peak I from Sephadex G-200 gel filtration (Fig. $5 B$ ) would not focus in a $5 \%$ thin layer polyacrylamide gel, whereas $\alpha_{2} \mathrm{M}$ in peak II did. (The $\alpha_{2} \mathrm{M}$ derivatives that could be focused by IEF are designated as $\alpha_{2} \mathrm{M}_{\mathrm{r}}$.)

Analysis of purified $\alpha_{2} \mathrm{M}$ and $\alpha_{2} \mathrm{M}_{\mathrm{f}}$ on SDS-polyacrylamide gel electrophoresis without reduction revealed no consistent differences between the two preparations (Fig. 7). However, when the preparations were reduced with DTT before electrophoresis, $\alpha_{2} \mathrm{M}$ showed one major band (average mol wt of 185,000), whereas $\alpha_{2} \mathrm{M}_{\mathrm{f}}$ showed two bands (mol wt 185,000 and 85,000 ). This suggests that the $\alpha_{2} \mathrm{M}_{\mathrm{f}}$ preparation contains not only intact $\alpha_{2} \mathrm{M}$ subunits, but also subunit derivatives, which apparently result from proteolytic cleavage during isolation, as a result of the interaction

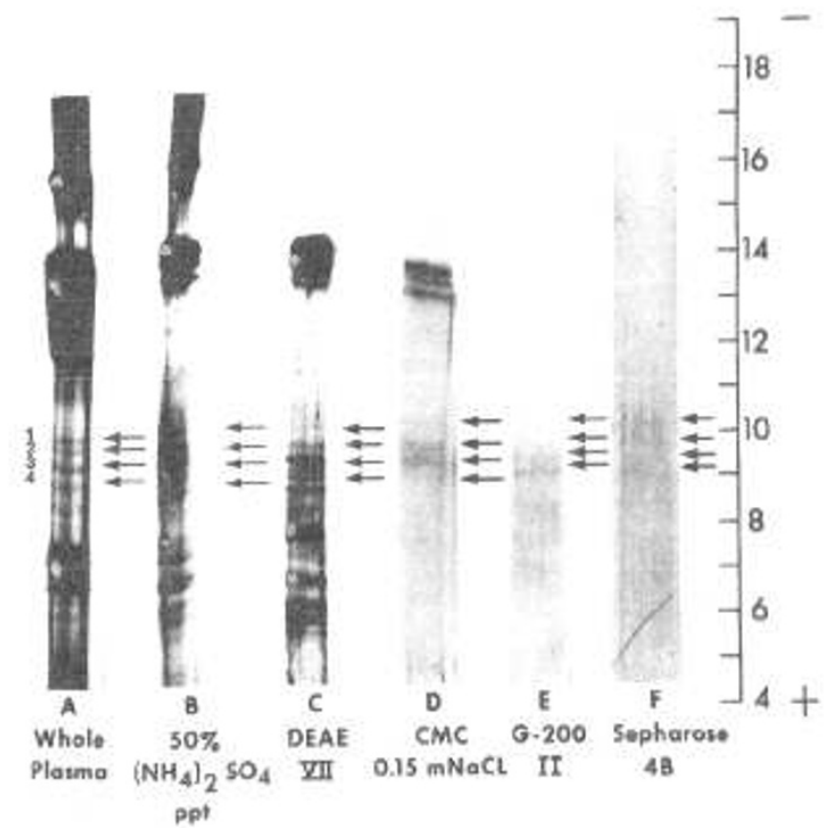

Fig. 4. Isolation of fragment of $\alpha_{2}$-macroglobulin $\left(\alpha_{2} \mathrm{M}_{\mathrm{f}}\right)$ as shown by isoelectric focusing. $A: 25 \mu \mathrm{l}$ whole activated normal plasma; $B: 25 \mu 150 \%$ $\left(\mathrm{NH}_{4}\right)_{2} \mathrm{SO}_{4}$-precipitable proteins $(50 \mathrm{mg} / \mathrm{ml}) ; C: 25 \mu$ l fraction VII from DEAE-cellulose chromatography $(50 \mathrm{mg} / \mathrm{ml}$ ) (see Fig. $5 A$ ); $D: 50 \mu 10.15$ M NaCl eluate from CM-cellulose $(C M C)$ chromatography $(30 \mathrm{mg} / \mathrm{ml})$; $E$ : $50 \mu 1$ peak II from Sephadex G-200 gel filtration $(30 \mathrm{mg} / \mathrm{ml}$ ) (see Fig. $5 B$ ); $F: 50 \mu$ l Sepharose $4 B$ eluate $(6 \mathrm{mg} / \mathrm{ml})$. The major bands found in purified preparations of $\alpha_{2} \mathrm{M}_{\mathrm{f}}$ are indicated by arrows. A centimeter scale shows the distance from the anode. 

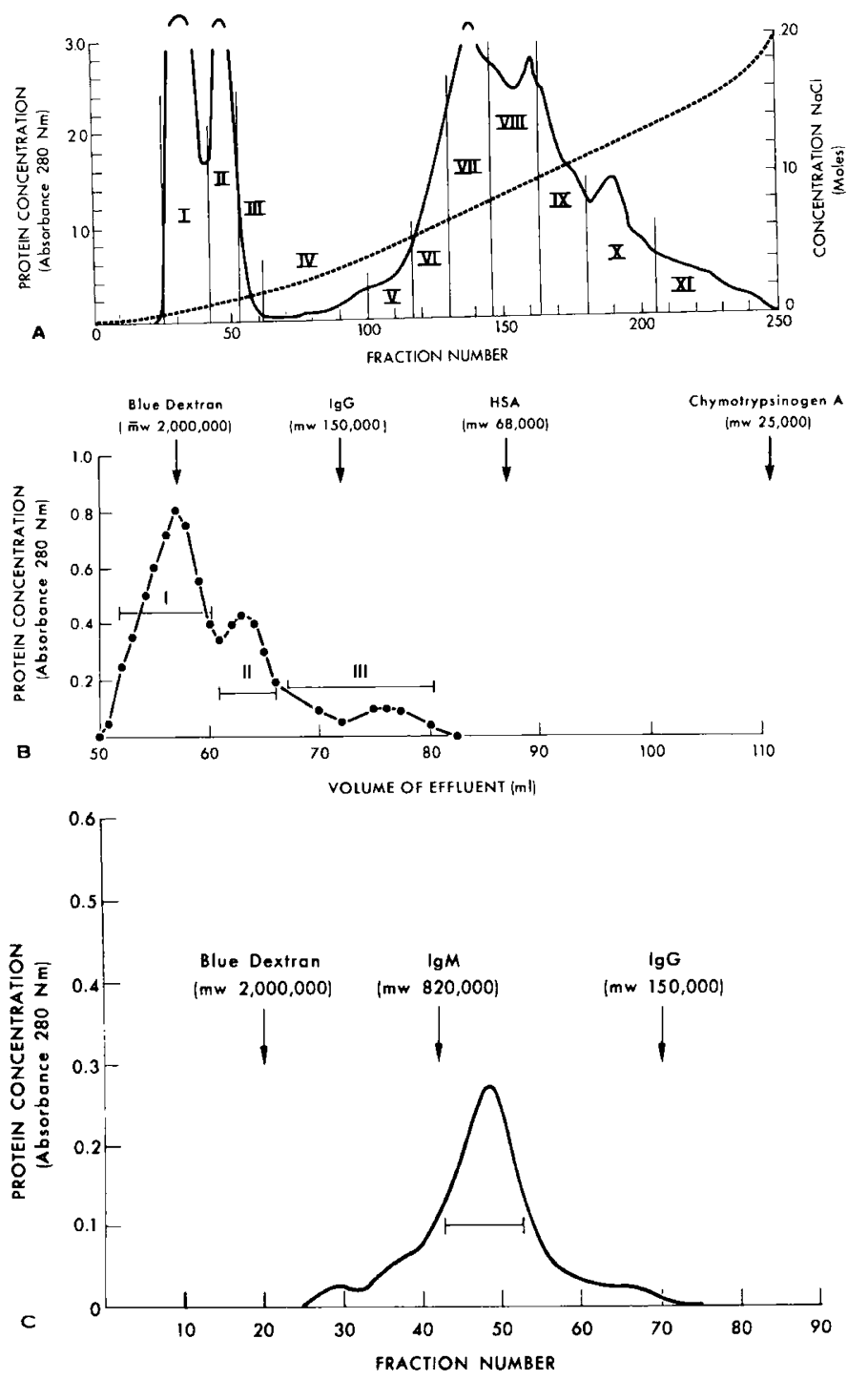

Fig. 5. A: DEAE-cellulose chromatography of $1,000 \mathrm{mg}\left(\mathrm{NH}_{4}\right)_{2} \mathrm{SO}_{4}-$ precipitable proteins. Chromatography was performed on a column, 3.5 $\times 43 \mathrm{~cm}$, in $0.01 \mathrm{M}$ phosphate buffer, $\mathrm{pH} 8.0$, with a continuous $\mathrm{NaCl}$ gradient. The flow rate was $25 \mathrm{ml} / \mathrm{hr}$. Four-milliliter fractions were collected. - : protein concentration (absorbance at $280 \mathrm{~nm}$ ); - - $\mathrm{NaCl}$ concentration (moles). B: Sephadex G-200 gel filtration of $24 \mathrm{mg}$, CM-cellulose $0.15 \mathrm{M}$ eluate. Elution was performed on a calibrated column, $2.2 \times 100 \mathrm{~cm}$, in $0.01 \mathrm{M}$ phosphate buffer- $0.15 \mathrm{M} \mathrm{NaCl}, \mathrm{pH} 8.0$, at a flow rate of $6 \mathrm{ml} / \mathrm{hr}$. The molecular weight markers used for calibration of the column are shown. HSA: human serum albumin. $C$ : Sepharose $4 \mathrm{~B}$ gel filtration of $15 \mathrm{mg}$ protein obtained after starch block electrophoresis. Elution was performed on a calibrated column, $2.2 \times 100 \mathrm{~cm}$, in 0.01 $M$ phosphate buffer- $0.15 \mathrm{M} \mathrm{NaCl}, \mathrm{pH} 8.0$, at a flow rate of $6 \mathrm{ml} / \mathrm{hr}$. The molecular weight markers used for calibration of the column are shown. Five-milliliter fractions were collected. The position of elution of $\alpha_{2}$-macroglobulin or $\alpha_{2}$-macroglobulin fragment is indicated by the bar.

of $\alpha_{2} \mathrm{M}$ with one or more of its proteolytically (esterolytically) active enzyme substrates found in plasma.

Additional evidence that $\alpha_{2} \mathrm{M}_{\mathrm{r}}$ is a mixture of intact $\alpha_{2} \mathrm{M}$ and $\alpha_{2} \mathrm{M}$ that has been proteolytically cleaved was obtained by reacting trypsin with purified $\alpha_{2} \mathrm{M}$ at different molar ratios (21). Electrophoresis of reduced samples (Fig. 7) showed that treatment of $\alpha_{2} \mathrm{M}$ with trypsin at increasing molar ratios of trypsin to $\alpha_{2} \mathrm{M}$ caused a progressive conversion of intact $\alpha_{2} \mathrm{M}$ subunits (mol wt 185,000) to their proteolytically cleaved derivatives (mol wt 85,000 ) and revealed a pattern nearly identical with that shown for $\alpha_{2} \mathbf{M}_{\mathbf{t}}$ without prior trypsin treatment (Fig. 7).
TRYPSIN BINDING CAPACITY OF $\alpha_{2} \mathrm{M}$ AND $\alpha_{2} \mathrm{M}_{\mathrm{t}}$

Further evidence was found when the functional capacities of $\alpha_{2} \mathrm{M}$ and $\alpha_{2} \mathrm{M}_{\mathrm{f}}$ preparations $(1 \mathrm{mg} / \mathrm{ml})$ were assessed by their ability to protect the esterolytic activity of trypsin from inhibition by SBTI $(400 \mu \mathrm{g} / \mathrm{ml})$. The results are shown in Figure 8 , with a curve depicting the esterolytic activity of trypsin without prior treatment for comparison. Addition of $\alpha_{2} \mathrm{M}$ to trypsin reduced the specific activity of the enzyme by about $19 \%$, which agrees closely with the $25 \%$ reduction reported previously (16) for the residual esterolytic activity of trypsin in an $\alpha_{2} \mathrm{M}$-trypsin complex. Addition of SBTI $(400 \mu \mathrm{g} / \mathrm{ml})$ alone totally abolished the esterolytic activity of trypsin. When $\alpha_{2} \mathrm{M}$ was added before SBTI, the esterolytic activity was protected up to a molar ratio (trypsin to $\alpha_{2} M$ ) of about 1.15 (Fig. 8). When the maximum binding capacity of $\alpha_{2} \mathrm{M}$ was exceeded, a decrease in the SBTI-resistant trypsin activity occurred, apparently because of destruction of $\alpha_{2} \mathrm{M}$ by excess trypsin (21). The value of 1.15 agrees well with values of 0.92 and 1.25 reported previously as the molar ratio of trypsin to $\alpha_{2} \mathrm{M}$ that is close to the normal binding capacity of $\alpha_{2} \mathrm{M}(3,21)$. In contrast, results for $\alpha_{2} M_{f}$ preparations indicated a major reduction in the functional capacity of the $\alpha_{2} \mathrm{M}$ in these preparations (Fig. 8). The esterolytic activity of trypsin was only protected up to a molar ratio of about 0.52 , indicating that $\alpha_{2} \mathrm{M}_{\mathrm{f}}$ preparations contain $\alpha_{2} \mathrm{M}$ that has been previously proteolytically cleaved or is already complexed to a proteolytic plasma enzyme.

\section{ISOELECTRIC FOCUSING OF PURIFIED $\alpha_{2} \mathrm{M}_{\mathrm{r}}$ AND $\alpha_{2} \mathrm{M}$}

Further evidence that $\alpha_{2} \mathrm{M}_{\mathrm{f}}$ is a proteolytically derived fragment of $\alpha_{2} \mathrm{M}$ was obtained by electrofocusing. Previous studies by Jones et al. (23) showed that treatment of $\alpha_{2} \mathrm{M}$ with urea causes the macroglobulin to disassociate into both intact subunit monomers ( $\mathrm{mol}$ wt 185,000 ) and subunit dimers (mol wt 340,000) (21). Since untreated $\alpha_{2} \mathrm{M}$ would not focus in a $5 \%$ polyacrylamide gel, apparently because of its large size (mol wt 670,000) (21), purified preparations of $\alpha_{2} \mathrm{M}$ were treated with $6 \mathrm{M}$ urea before electrofocusing. $\alpha_{2} \mathrm{M}$ pretreated with urea showed four major bands, all with pl values lower than those of bands 1 and 2 from urea-treated or untreated $\alpha_{2} \mathrm{M}_{\mathrm{f}}$ preparations (Fig. 9). However, treatment of $\alpha_{2} \mathrm{M}$ preparations with trypsin and then urea produced a banding profile similar to that of urea-treated $\alpha_{2} M_{f}$ (Fig. 9).

\section{$\alpha_{2} \mathrm{M}$ AND ARGININE ESTERASE ACTIVITY}

As shown previously (Fig. 3, Table 1), analysis of whole activated plasma samples from $\mathrm{CF}$ homozygotes and obligate heterozygote carriers by isoelectrofocusing indicated a quantitative deficiency in bands 1 and 2 . The preceding results indicate that these bands represent fragments of $\alpha_{2} \mathrm{M}$ derived from proteolytic cleavage of the parent molecule. To determine whether a deficiency in $\alpha_{2} \mathrm{M}_{\mathrm{f}}$ production by the majority of CF homozygote and obligate heterozygote samples might be due to decreased levels of $\alpha_{2} \mathrm{M}$, we quantitated $\alpha_{2} \mathrm{M}$ levels by single radial immunodiffusion. No significant difference between $\alpha_{2} \mathrm{M}$ levels in obligate heterozygote carriers and normal controls was found. CF homozygotes showed slightly increased $\alpha_{2} \mathrm{M}$ levels but all levels were within the normal range for $\alpha_{2} \mathrm{M}$ (Table 1).

$\alpha_{2} \mathrm{M}$ purified from two CF homozygote donors (C7422 and C2045 in Table 1) was nearly identical with $\alpha_{2} \mathrm{M}$ from normal controls when analyzed by SDS-polyacrylamide gel electrophoresis, both before and after reduction with DTT. Thus, CF $\alpha_{2} \mathrm{M}$ apparently is not abnormal in molecular weight or gross subunit structure. The same CF $\alpha_{2} \mathrm{M}$ preparations did, however, have slightly reduced binding capacity for trypsin relative to normal $\alpha_{2} \mathrm{M}$ (1.00 vs. $1.15 \mathrm{~mol}$ trypsin $\left./ \mathrm{mol} \alpha_{2} \mathrm{M}\right)$. This difference accounts for a difference of $7 \mu \mathrm{mol}$ TAME hydrolyzed $/ \mathrm{min} / \mathrm{mg}$ $\alpha_{2} \mathrm{M}$.

An alternative explanation for the observed deficiency in bands 1 and 2 was a deficiency in proteolytic cleavage of $\alpha_{2} \mathbf{M}$, possibly because of a decreased level of active proteolytic (esterolytic) 


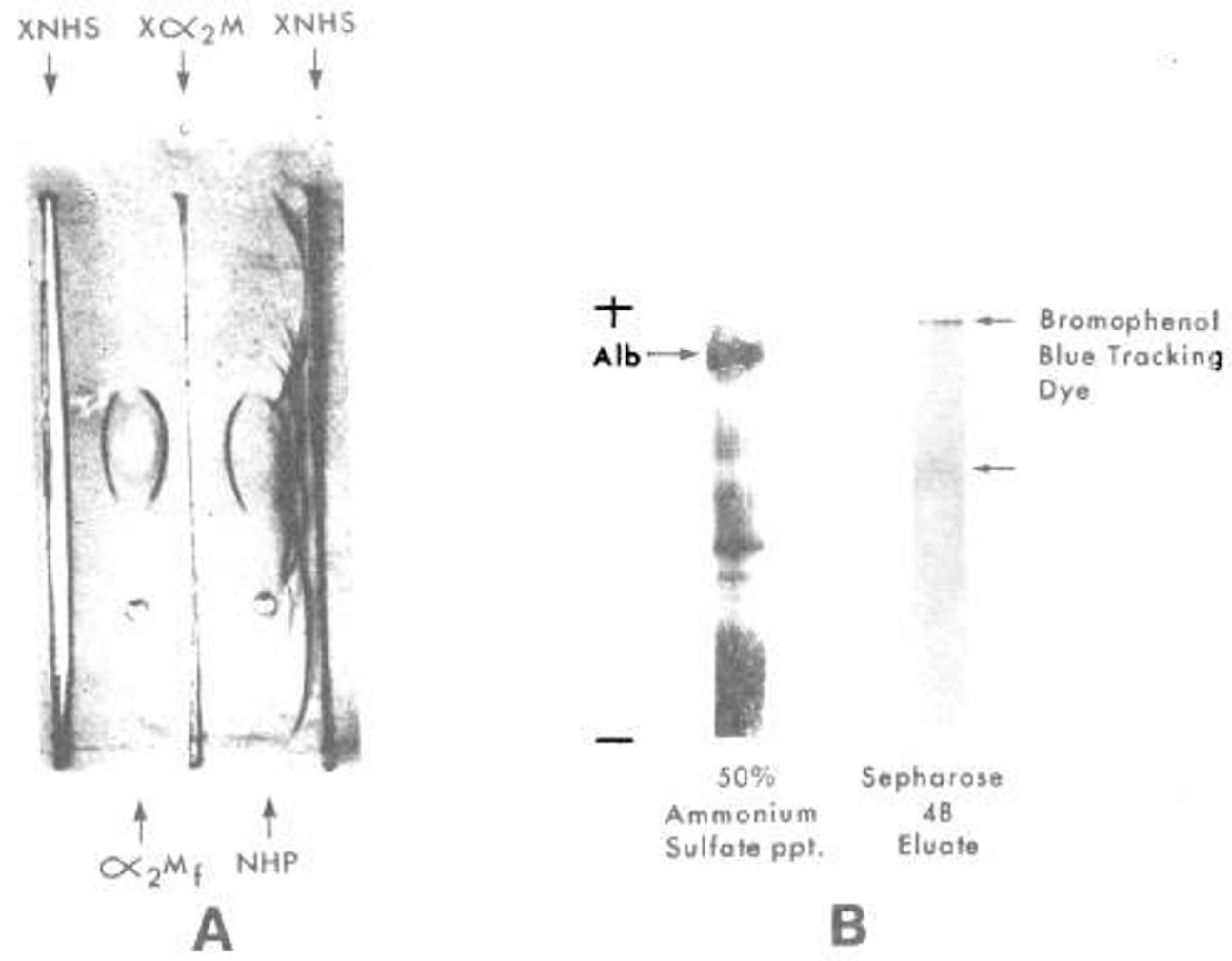

Fig. 6. $A$ : results of analysis of Sepharose $4 \mathrm{~B}$ eluate $(6 \mathrm{mg} / \mathrm{ml})$ by immunoelectrophoresis. Patterns were developed with rabbit-anti-whole human serum $(X N H S)$ or rabbit-anti- $\alpha_{2}$-macroglobulin $\left(X \alpha_{2} M\right)$ as indicated. The patterns for whole normal human plasma $(N H P)$ are also shown. $B$ : results of electrophoresis of $20 \mu \mathrm{l}$ Sepharose $4 \mathrm{~B}$ eluate $(6 \mathrm{mg} / \mathrm{ml})$ and $20 \mu 150 \%$ precipitable proteins $(50 \mathrm{mg} / \mathrm{ml})$. The position of albumin is indicated.

enzyme activity in CF plasma. Therefore, we analyzed all samples from CF homozygotes, heterozygote carriers, and normal controls for total arginine esterase activity (esterolytic activity) in the presence and absence of SBTI $(400 \mu \mathrm{g} / \mathrm{ml})$. Samples from CF homozygotes and obligate heterozygote carriers showed decreased levels of total arginine esterase activity and decreased levels of SBTI-inhibited esterolytic activity as compared with the normal control samples (Table 1). Examination of samples indicated that, with the exception of CF samples found to have a strong band 5 (Fig. 3, Table 1), there appeared to be a correlation between decreased arginine esterase activity and a decrease observed in the $\alpha_{2} \mathbf{M}_{\mathbf{t}}$ bands. Examination of the SBTI-resistant and SBTI-inhibited activities of CF samples with a strong band 5 , in each case revealed a larger amount of SBTI-resistant activity relative to SBTI-inhibited activity in these samples as compared with normal control samples. There was no obvious correlation between age, sex, or severity of the disease and abnormalities in IEF banding profiles of CF samples in these preliminary studies. However, further studies with samples from more patients are required before definite conclusions can be drawn.

\section{DISCUSSION}

Harpel (2l) has shown that the subunit structure of $\alpha_{2} \mathrm{M}$ is altered by interaction with the proteolytic enzymes it inhibits. $\alpha_{2} \mathrm{M}$ that has not formed a complex with a protease consists of four subunit chains of molecular weight approximately 185.000 each. Upon complex formation with trypsin, plasmin, thrombin, kallikrein, and possibly other plasma proteases, $\alpha_{2} \mathrm{M}$ is proteolytically cleaved at the same region in each subunit chain, resulting in the production of a single proteolytic derivative with a molecular weight approximately half that of the subunit chain $(85,000)$ (Fig. 7).

Our results suggest that $\alpha_{2} M_{r}$ may be this proteolytic subunit derivative of $\alpha_{2} \mathrm{M}$. Evidence that $\alpha_{2} \mathrm{M}$, does not represent a plasma protease bound to $\alpha_{2} \mathrm{M}$ during our isolation procedure is derived from the results showing that plasma proteases do not have pI values near $5.5(24)$; that plasminogen was not found associated with preparations of $\alpha_{2} M_{\mathrm{r}}$ as assessed by CIE: and that $\alpha_{2} \mathrm{M}_{\mathrm{r}}$ could be derived from intact $\alpha_{2} \mathrm{M}$ by treatment with trypsin or with thrombin (49). The fact that $\alpha_{2} \mathrm{M}_{\mathrm{f}}$ preparations will focus in a $5 \%$ polyacrylamide gel with $4 \mathrm{M}$ urea added, whereas intact $\alpha_{2} \mathrm{M}$ will not, maly be related to the observation that intrachain disulfide bonds in $\alpha_{2} \mathrm{M}$ subunits which have been cleaved by proteolysis may be more susceptible to denaturation by urea (23).

$\alpha_{2} \mathrm{M}$ appears to participate in the regulation of several circulating enzyme systems, as it forms complexes with plasmin (18. 19. $21,24)$, thrombin $(26,46)$, and kallikrein $(20)$. In addition, $\alpha_{2} M$ has been found to bind trypsin, chymotrypsin, cathepsins, and other endopeptidases $(3,21)$. Figure 10 shows a generalized diagram of the possible points in the hemostatic, inflammatory, and complement pathways where $\alpha_{2} \mathrm{M}$ has been shown to interact and possibly function as a regulatory agent $(24,40,41)$. The double-headed arrows leading to and from $\alpha_{2} \mathrm{M}$ indicate the points of interaction of $\alpha_{2} \mathrm{M}$ with these systems.

Before activation of Hageman factor by glass, ellagic acid, or kaolin (40), the plasma proteases (esterases) are in an inactive or proenzyme form $(21,24,40)$ and will not interact with $\alpha_{2} \mathrm{M}(3,16$. 21 ). Therefore, $\alpha_{2} \mathrm{M}$ is not proteolytically cleaved, and proteolytic derivatives $\left(\alpha_{2} \mathrm{M}_{\mathrm{f}}\right)$ cannot be observed by isoelectric focusing of whole plasma (Fig. 2). When Hageman factor is activated it can initiate the conversion of the proteases to active forms capable of complexing to $\alpha_{2} \mathrm{M}$ and of interacting with systems that generate kinin and anaphylatoxin (Fig. 10) $(23,24,40,41)$.

In activated plasma samples from most $C F$ homozygotes and heterozygote carriers, decreased amounts of $\alpha_{2} \mathrm{M}_{\mathrm{f}}$ are noted by isoelectric focusing (Table 1). The finding that 3 of $12 \mathrm{CF}$ patients were not markedly deficient in $\alpha_{2} \mathrm{M}_{\mathrm{f}}$ (Fig. 3, Table 1) may be further evidence of genetic heterogeneity in the clinical entity known as CF. The occurrence of a strong band 5, an extra band 


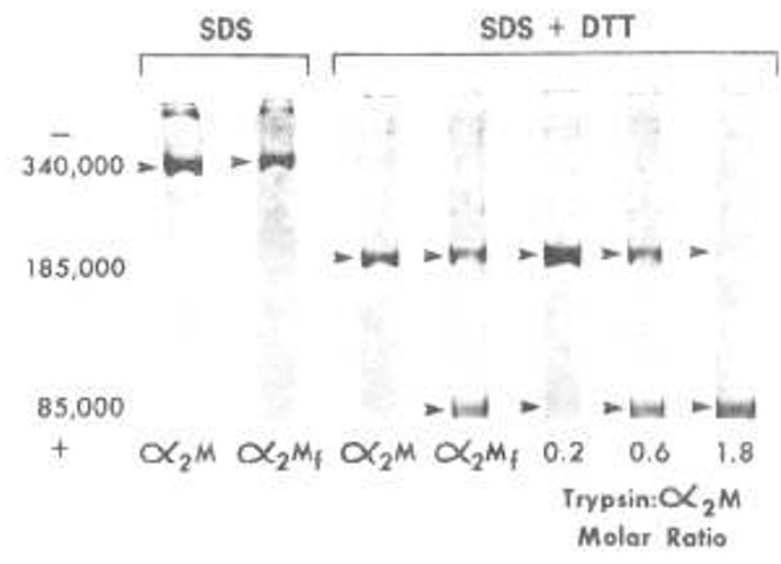

Fig. 7. Results of SDS-polyacrylamide gel electrophoresis of $\alpha_{2}$-macroglobulin $\left(\alpha_{2} M\right)$ and $\alpha_{2} \mathrm{M}$ fragment $\left(\alpha_{2} M_{\mathrm{f}}\right) \cdot \alpha_{2} \mathrm{M}(2 \mathrm{mg} / \mathrm{ml})$ or $\alpha_{2} \mathrm{M}_{\mathrm{f}}(2$ $\mathrm{mg} / \mathrm{ml}$ ) preparations were mixed $1: 1$ with either $10 \mathrm{M}$ urea plus $1 \%$ sodium dodecyl sulfate $(S D S)$ or reduced with a similar solution containing $14 \mathrm{mM}$ dithiothreitol (DTT). Although not shown in this figure, at times unreduced $\alpha_{2} M_{r}$ preparations showed small amounts of the 185,000 molecular weight band. The results of prior treatment of $\alpha_{2} M(2 \mathrm{mg} / \mathrm{ml})$ with trypsin at different trypsin to $\alpha_{2} \mathrm{M}$ molar ratios are also shown. The highest concentration of trypsin was $88 \mu \mathrm{g}$ corresponding to a trypsin to $\alpha_{2} \mathrm{M}$ molar ratio of 1.8. The approximate molecular weight of bands obtained before and after reduction is indicated. Twenty-microliter samples were analyzed.

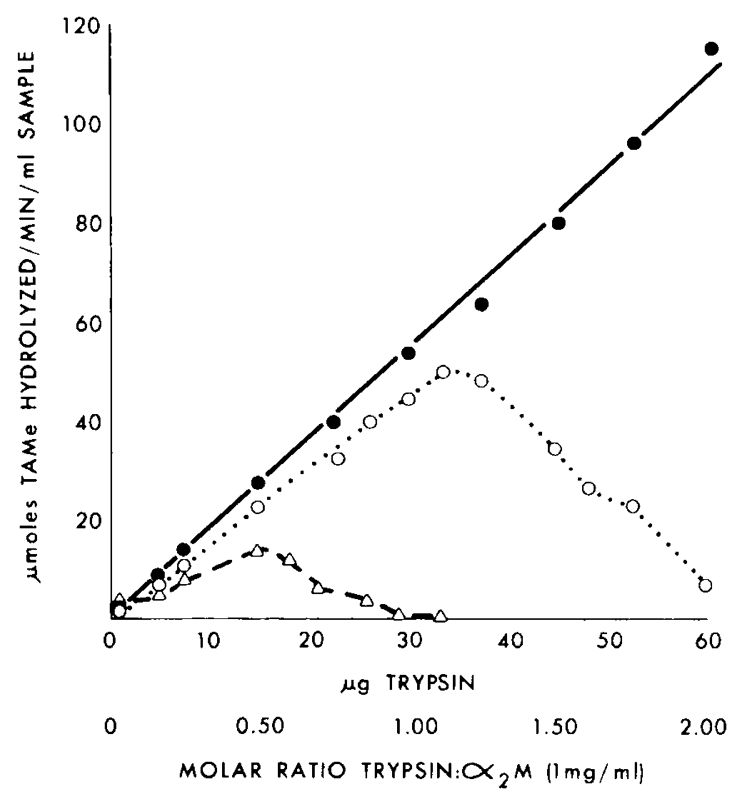

Fig. 8. Hydrolysis of tosyl arginine methyl ester (TAMe) by trypsin. - a a a hydrolyzed by mixtures of trypsin plus $\alpha_{2}$-macroglobulin $\left(\alpha_{2} M\right)(1 \mathrm{mg} / \mathrm{ml})$ plus soybean trypsin inhibitor (SBTI) $(400 \mu \mathrm{g} / \mathrm{ml}) . \Delta--\Delta$ : TAME hydrolyzed by mixtures of $\alpha_{2} M$ fragment preparations $(1 \mathrm{mg} / \mathrm{ml})$ plus trypsin plus SBTI $(400 \mathrm{mg} / \mathrm{ml})$.

above band 5, and an abnormally high SBTI-resistant fraction suggests that these patients are not normal per se. Since $\alpha_{2} \mathrm{M}$ levels are normal in CF homozygotes and obligate heterozygote carriers. this finding suggests a decreased proteolysis of $\alpha_{2} \mathrm{M}$ in plasma from such individuals. Decreased proteolysis of $\alpha_{2} \mathrm{M}$ may be due to several different mechanisms, which are not necessarily mutually exclusive. Among these possibilities are the following: $(a)$ Plasma proteases in general may not be activated to levels found in normal plasma, because of an abnormality in Hageman factor or in the

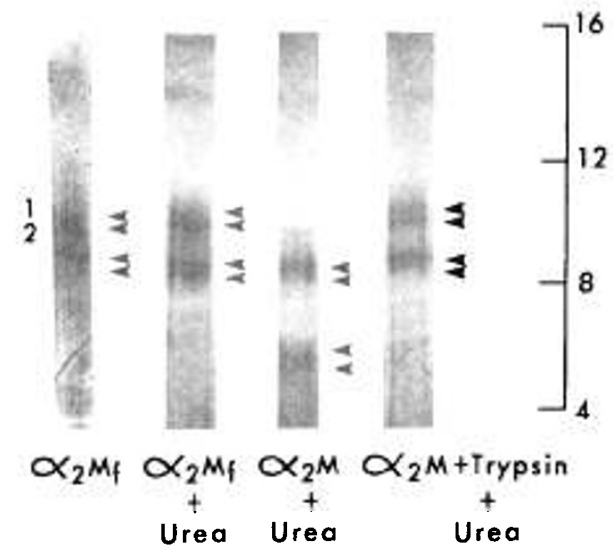

Fig. 9. Results of isoelectric focusing of $100 \mu 1 \alpha_{2}$-macroglobulin fragment $\left(\alpha_{2} M_{f}\right) ; 100 \mu \mathrm{l} \quad \alpha_{2} \mathrm{M}_{\mathrm{f}}$ plus urea; $\alpha_{2}$-macroglobulin $\left(\alpha_{2} M\right)$ plus urea; and $100 \mu \mathrm{l} \alpha_{2} \mathrm{M}$ plus trypsin (trypsin to $\alpha_{2} \mathrm{M}$ molar ratio of 1.5) plus urea. The final concentration of $\alpha_{2} \mathrm{M}$ was $2 \mathrm{mg} / \mathrm{ml}$ in each case. The final urea concentration used was $6 \mathrm{M}$. The centimeter scale shows the distance from the anode.

activation of Hageman factor. (b) A specific protease may be abnormal structurally or may remain partially in proenzyme form. (c) There may be a genetically determined abnormality in the structure of $\alpha_{2} \mathrm{M}$, primarily at the active site, thus decreasing its binding affinity for the plasma proteases. (d) The active site of $\alpha_{2} \mathrm{M}$ may be blocked by an inhibitor, reducing its interaction with the proteases. (e) The active site of the proteases may be blocked either before or after their conversion to active forms, inhibiting their ability to interact with $\alpha_{2} \mathrm{M}$.

Evidence for possibilities $a, b$, and $e$ is found in the work of Rao et al. (39) and Rao and Nadler (38) and in the results of this study (Table 1), which collectively point to a deficiency in arginine esterase activity in CF plasma. This esterase activity is thought to be due primarily to plasma kallikrein activated by Hageman factor (9), although no attempt has been made to exclude a contribution to this activity by plasmin or other plasma proteases which are known to have esterolytic activity and can hydrolyze TAME (40).

Possibilities $c$ and $d$, however, seem to us to be more attractive. A structural abnormality in, or a blockage of, the binding of $\alpha_{2} \mathrm{M}$ could decrease the inhibition of kallikrein, plasmin, and plasminogen activator (among other plasma proteases). $\alpha_{2} \mathrm{M}$ is thought to be the major inhibitor of plasmin (24). Plasmin, if not effectively inhibited, could participate in increased activation of kallikrein and thus increased production of kinins brought about by the conversion of kininogen to kinin. In addition, increased production of $\mathrm{C} 3 \mathrm{a}$ and chemotactic factors could occur through the action of plasmin on C 3 and C1s (Fig. 10) $(24,40,41)$.

Conover et al. (13) have suggested that the CF factor may be a $\mathrm{C} 3 \mathrm{a}$ or kinin-like molecule and have speculated how this molecule could cause the pathophysiology of CF. Considerable evidence now suggests that the CF factor binds or complexes to $\operatorname{lgG}(2,4$, 50). Evidence that $C 3$ a can complex to $\operatorname{IgG}$ has also been reported (35). In the hypothesis of Conover et al. (13) and in a similar theory which we put forth (48), once CF factor or C3a is complexed to $\mathrm{IgG}$ it is protected from its inhibitor. Conover et al. assumed that a defect in the anaphylatoxin inactivator (AI) or another enzyme similar to carboxypeptidase B must occur in $\mathrm{C} / \mathrm{F}$ to explain the accumulation of $\mathrm{C} 3 \mathrm{a}$ or $\mathrm{CF}$ factor. However, a defect in $\mathrm{Al}$ need not be postulated, if $\mathrm{C} 3 \mathrm{a}$ is protected from $\mathrm{AI}$ when it is complexed to IgG. Furthermore, Lieberman (29) has shown recently that carboxypeptidase B-like activity is normal in CF serum.

Instead of a defect in $\mathrm{AI}$ or a similar exopeptidase, we suggest that the CF factor, if it is $\mathrm{C} 3 \mathrm{a}$ or kinin-like material, may be overproduced in $\mathrm{CF}$ due to the combined production of $\mathrm{C} 3 \mathrm{a}$ and kinin by the classic inflammatory and complement pathways and 


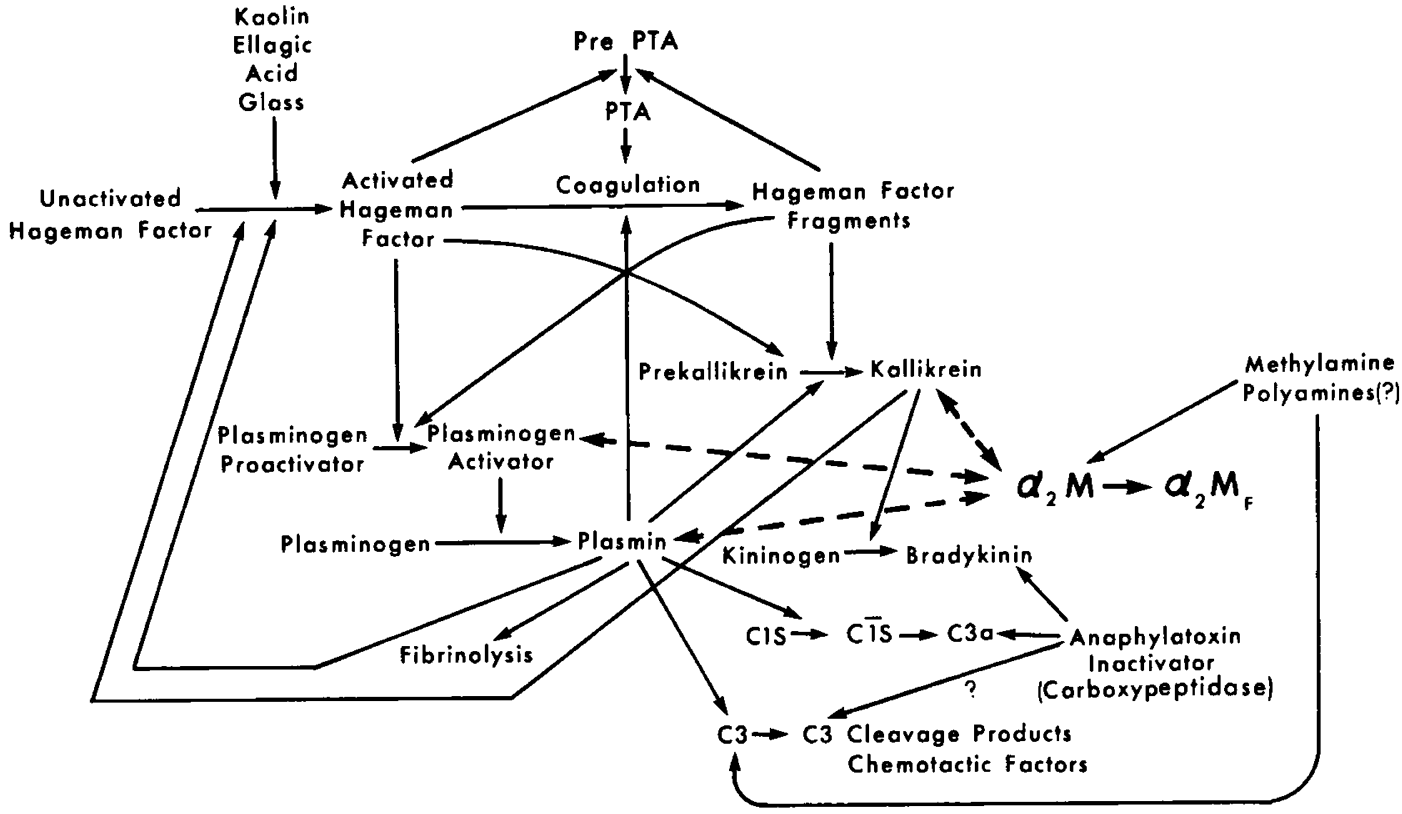

Fig. 10. Diagram illustrating the points of interaction of $\alpha_{2}$-macroglobulin $\left(\alpha_{2} M\right)$ with the hemostatic, inflammatory and complement pathways and the interrelationship of these systems (modified from Kaplan (24) by permission of Microvascular Research). $\alpha_{2} M_{f}: \alpha_{2} M$ fragment; PTA: plasma thromboplastin antecedent.

as a result of abnormally elevated plasmin-like activity brought about by an abnormality in $\alpha_{2} \mathrm{M}$, its primary plasma inhibitor. If a defect in $\alpha_{2} \mathrm{M}$ is responsible indirectly for the pathophysiology of $\mathrm{CF}$, then the etiology of the disease would be roughly analogous to that of heredity angioneurotic edema, in that a deficiency in $\mathrm{Cl}$ esterase inhibitor has been found to be indirectly responsible for the pathophysiology of that disease (41). A concomitant decrease in total arginine esterase activity or kallikrein activity in CF might be explained by assuming (1) hyperconversion of prekallik rein to kallikrein, brought about by plasmin (40), with subsequent inhibition of kallikrein by $\alpha_{1}$ antitrypsin or $\mathrm{Cl}$ esterase inhibitor (24, 40); (2) feedback inhibition of Hageman factor activation by uninhibited plasmin; or (3) a concurrent defect in kallikrein, or another protease, but not plasmin.

Although a structurally abnormal active site on $\alpha_{2} M$ could explain a decrease in its proteolysis, blockage of the active site would have a similar effect. Inhibition of trypsin and other plasma proteases by SBTI and presumably by $\alpha_{2} \mathrm{M}$ may involve proteolytic cleavage at a single arginine or lysine residue in the inhibitor, located within a peptide loop formed by intrachain disulfide bridging $(21,27)$. A covalent bond is then formed between the enzyme and the inhibitor, involving an acyl enzyme or tetrahedral intermediate, in which a serine residue at the active site of the protease (trypsin) forms an ester bond with the carboxyl of an arginine or lysine residue at the active site of the inhibitor $(21,27)$. It is known that methylamine can destroy the ability of $\alpha_{2} \mathrm{M}$ to complex with plasma proteases $(44,47)$. In fact, methylamine at concentrations of about $0.25 \mathrm{M}$ causes the breakdown of $\alpha_{2} \mathrm{M}$ into smaller protein derivatives with faster electrophoretic mobility (3, $44,47)$. In preliminary studies (49), we have found that methylamine causes no gross structural changes in $\alpha_{2} \mathrm{M}$ at concentrations of $0.05 \mathrm{M}$ or lower (as assessed by isoelectric focusing and SDSpolyacrylamide gel electrophoresis), whereas methylamine causes a reduction in the trypsin binding capacity of $\alpha_{2} \mathrm{M}$. The binding site of methylamine to $\alpha_{2} \mathrm{M}$ has not been identified, but binding may occur near or at the lysine or arginine that is the site of cleavage by the serine proteases. Further research will be required to fully answer this problem.

It has been recently shown that CF may involve an abnormality in polyamine metabolism $(8,36,43)$ and that excess spermidine is found in the plasma of CF patients (36). It might be that this polyamine or a derivative of it could bind to the active site of $\alpha_{2} \mathrm{M}$ in a manner analogous to that of methylamine and thus cause a decrease in the effective binding affinity of $\alpha_{2} \mathrm{M}$ for proteases. Alternatively, it might bind to one or more proteases, altering their activity and binding affinity for $\alpha_{2} \mathrm{M}$. Experiments concerned with assessing the possible inhibitory effect of polyamines or their derivatives on the functional activity of $\alpha_{2} \mathrm{M}$ and selected plasma proteases are currently being pursued in this laboratory and will be published in a subsequent report (49).

\section{CONCLUSION}

The results of this investigation have shown that activated plasma samples from $C F$ patients and obligate heterozygote carriers for $C F$ are deficient in a derivative of $\alpha_{2} \mathrm{M}$, which results presumably from proteolysis of intact $\alpha_{2} \mathrm{M}$ subunits by plasma proteases. Several mechanisms are hypothesized to explain this deficiency. The most attractive explanations are either $(l)$ a structurally abnormal active site on $\mathrm{CF} \alpha_{2} \mathrm{M}$, which would result in a decreased binding affinity of $\mathrm{CF} \alpha_{2} \mathrm{M}$ for the plasma protease, or (2) blockage of the active site of CF $\alpha_{2} \mathrm{M}$ by polyamine derivatives which are known to be found in elevated amounts in CF plasma.

Certainly further research is indicated to explore the possible relationship of an abnormality in polyamine metabolism to a deficiency in proteolysis of $\alpha_{2} \mathrm{M}$ and to elucidate the involvement of either defect to the pathophysiology of cystic fibrosis. However, it may well be that an abnormality in $\alpha_{2} \mathrm{M}$-protease interactions, possibly coupled with an abnormality in polyamine metabolism, could explain the presence of CF factor(s) in cystic fibrosis.

\section{REFERENCES AND NOTES}

1. Barnett, D. R., and Bowman, B. H.: Cystic fibrosis ciliary inhibitor. Pediat. Res., 8: 687 (1974).

2. Barnett, D. R.. Kurosky, A., Bowman, B. H., Hutchison. H. T., Schmoyer, I., and Carson, S. D.: Cystic fibrosis: Molecular weight estimation of the ciliary inhibitor. Tex. Rep. Biol. Med., 31: 703 (1973).

3. Barrett. A. J., and Starkey. P. M.: The interaction of $\alpha_{2}$-macroglobulin with proteinases. Biochem. J., 133: 709 (1973).

4. Beratis, N. G.. Conover, J. H., Conod. E. J.. Bonforte. R. J.. and Hirschhorn. K. Studies on ciliary diskinesia factor in cystic fibrosis. III. Skin fibroblasts and cultured amniotic fluid'cells. Pediat. Res., 7: 958 (1973).

5. Bowman, B. H., Barnett, D. R., and Matalon, R.: Detection and characterization of the cystic fibrosis ciliary imhibitor. In: J. A. Mangos and R. C. Talamo: Fundamental Problems of Cystic Fibrosis and Related Diseases. p. 29 (Intercontinental Medical Book Corporation. New York, 1973).

6. Bowman, B. H. Lockhart, L. H. Herzberg, V L. Barnett, D. R. Armstrong, 
D., and Kramer, J.: Cystic fibrosis: Synthesis of ciliary inhibitor by amniotic cells. Clin. Genet. 4: 461 (1973).

7. Bowman, B. H., McCombs, M. L., and Lockhart, L. H.: Cystic fibrosis: Characterization of the inhibitor to ciliary action in oyster gills. Science, 167: 871 (1970).

8. Cohen, L. F., Farrell, P. M., Willison, J. W., and Lundgren, D. W.: Localization of spermidine (Spd) and spermine (Spm) in blood of cystic fibrosis (CF) and control subjects. Pediat. Res., 9: 312 (1975).

9. Colman, R. W., Mattler, L., and Sherry, S.: Studies on the prekallikrein (kallikreinogen)-kallikrein enzyme system of human plasma. II. Evidence relating the kaolin-activated arginine esterase to plasma kallikrein. J. Clin. Invest., 48: 23 (1969).

10. Conneally, P. M., Merritt, A. D., and Yu, P.: Cystic fibrosis: Population genetics. Tex. Rep. Biol. Med., 3I: 639 (1973).

11. Conover, J. T., Bonforte, R. J., Hathaway, P., Paciuc, S., Conod, E. J., Hirschhorn, K., and Kobel, F. B.: Studies, on ciliary dyskinesia factor in cystic fibrosis. 1. Bioassay and heterozygote detection in serum. Pediat. Resi, 7: 220 (1973).

12. Conover, J. H., and Conod, E. J.: Complement in cystic fibrosis Lancet, $i: 47$ (1975).

13. Conover, J. T., Conod, E. J., and Hirschhorn, Ks. Studies on ciliary dyskinesia factor in cystic fibrosis. IV. Its possible identification as anaphylatoxin (C3a)-IgG complex. Life Sci., 14: 253 (1974).

14. Davis, B. J.: Disc electrophoresis. II. Method and application to human serum proteins. Ann. N. Y. Acad. Sci., 12l: 404 (1964)

15. Fairbanks, G., Steck, T. L., and Wallach, D. F. H.: Electrophoretic analysis of the major polypeptides of the human erythrocyte membrane. Biochemistry, 10: 2606 (1971).

16. Ganrot, P. O.: $\alpha_{2}$-antitrypsin activity and different trypsin substrates.Clin. Chim. Acta, 13: 518 (1966).

17. Ganrot, P. O.: Separation of two trypsin-binding $\alpha_{2}$-globulins of human serum. Clin. Chim. Acta, 13: 597 (1966).

18. Ganrot, P. O.: Inhibition of plasmin activity by $\alpha_{2}$-macroglobulins. Clin. Chim. Acta, 16: 328 (1967).

19. Ganrot, P. O.: On the determination of molar concentration of plasmin and plasmin inhibitors. Acta Chem. Scand., 21: 595 (1967)

20. Harpel, P. C.: Human plasma alpha 2-macroglobulin, an inhibitor of plasma kallikrein. J. Exp. Med., $132 \div 329 \cdot(-1970)$.

21. Harpel, P. C.: Studies on human plasma $\alpha_{2}$ macroglobulin-enzyme interactions: Evidence for proteolytic modification of the subunit chain structure. J. Exp. Med., 138: 508 (1973).

22. Hirschhorn, H.: Genetic studies in disease: In! J. A. Mangos and R. C. Talamo: Fundamental Problems of Cystic Fibrosis and Related Diseases, p. 11 (Intercontinental Medical Book Corporation. New York, 1973).

23. Jones, J. M., Creeth, J. M., and Kerwick, R. A.: Thiol reduction of human $\alpha_{2}$ macroglobulin. The subunit structure. Biochem. J., 127: 187 (1972).

24. Kaplan, A. P.: Trends in microvascular research: The Hageman factor dependent pathways of human plasma. Microvasc. Res., 8: 97 (1974).

25. Kunkel, H. G., and Trautman, R.: Zone electrophoresis in various types of support media. In: M. Bier: Electrophoresis, p. 225 (Academic Press, New York, 1959).

26. Lanchantin, G. F., Plesset, M. L., Friedman, J. A., and Hart, D. W.: Dissociation of esterolytic and clotting activities of thrombin by trypsin-binding macroglobulin. Proc. Soc. Exp. Biol. Med., 121: 444 (1966).

27. Laskowski, M., and Sealock, R. W.: Protein proteinase inhibitors-molecular aspects. In: P. Boyer: The Enzymes, Ed. 3, Vol. 3, p. 375 (Academic Press, New York, 1971):

28. Lieberman, $J$.: Complement components in cystic fibrosis. Lancet, $i: 1230$ (1974).

29. Lieberman, J.: Carboxypeptidase-B-like activity and C3 in cystic fibrosis. In: Cystic Fibrosis Club Abstracts, p. 44 (Cystic Fibrosis Foundation, Atlanta, 1975).

30. Lowry, O. H., Rosebrough, N. J., Farr, A. L., and Randall, R. J.: Protein measurement with the Folin phenol reagent. J. Biol. Chem., 193: 265 (195I).

31. Mangos, J. A., and McSherry, N. R.: Studies on the mechanism of inhibition of sodium transport in cystic fibrosis of the pancreas. Pediat. Res., 2: 378 (1968).

32. Margolis, J.: The mode of action of Hageman factor in the release of plasma kinin. J. Physiol., 151: 238 (1960).

33. McCombs, M. L.: Research in cystic fibrosis: A review. Tex. Rep. Biol. Med., 31: $615(1973)$

34. McConnell, D. J.: Inhibitors of kallikrein in human plasma. J. Clin. Invest., 51:
1611 (1972).

35. Molenaar, J., Muller, M., Engelfriet, C., and Pondman, K.: Changes in antigenic properties of human $\mathrm{C} 3$ upon activation and conversion by trypsin. J. Immunol., 112: 1444 (1974).

36. Munro, G. F., Lederman, M., and Miller, R. A.: Polyamines in blood and fibroblasts from cystic fibrosis patients. In: Cystic Fibrosis Club Abstracts, p. 7 (Cystic Fibrosis Foundation, Atlanta, 1975).

37. Ouchterlony, O., and Nilsson, L. A.: Immunodiffusion and immunoelectrophoresis. In: D. M. Weir: Handbook of Experimental Immunology, p. 191 (Blackwell Scientific Publications, London, 1974).

38. Rao, G. J. S., and Nadler, H. L.: Arginine esterase in cystic fibrosis of the pancreas. Pediat. Res., 8: 684 (1974).

39. Rao, G. J. S., Posner, L. A., and Nadler, H. L.: Deficiency of kallikrein activity in plasma of patients with cystic fibrosis. Science, 177: 610 (1972).

40. Ratnoff, O. D. Some relationships among homostasis, fibrinolytic phenomena, immunity, and the inflammatory response. Advan. Immunol., 10:145 (1969).

41. Ratnoff, $O$. D.: The interrelationship of clotting and immunologic mechanisms. In: R. A. Good and D. W. Fisher: Immunobiology, p. 135 (Singner, Connecticut, 1971).

42. Raymond, S.: Acrylamide gel electrophoresis. Anm, N. Y. Acad. Sci., 12I: 350 (1964).

43. Rennert, O., Frias, J., and Lapointe, D.: Methylation of RNA and polyamine metabolism in cystic fibrosis. In: J. A. Mangos and R. C. Talamo: Fundamental Problems of Cystic Fibrosis and Related Diseases p. 41 (Intercontinental Medical Book Corporation, New York, 1973).

44. Saunders, R., Dyce, B. J., Vannier, W. E., and Haverback, B. D.: The separation of alpha-2 macroglobulin into five components with differing electrophoretic and enzyme-binding properties. J. Clin. Invest., 50: 2376 (1971).

45. Siegelman, A. M., Carlson, A. S., and Robertson, T.: Investigation of serum trypsin and related substances. I. The quantitative demonstration of trypsin like activity in human blood serum by a micromethod. Arch. Biochem. Biophys., 97: 159 (1962).

46. Steinbuch, M., Biatrix, C., and Josso, F.: Action antiprotéase de l' $\alpha_{2}$-macroglobulin. Il. Son role l'antithrombine progressive. Rev. Franc. Études Clin. Biol., 13: 179 (1968).

47. Steinbuch, M., Pejaudier, L., Quentin, M., and Martin, V.: Molecular alteration of $\alpha_{2}$-macroglobulin by aliphatic amines. Biochim. Biophys. Acta, I54: 228 (1968).

48. Wilson, G. B.: Studies on the cystic fibrosis serum factor and on the nature of the ciliary beat of Colpidium striatum (Ph.D. thesis, University of California at Los Angeles). Dissert. Abstr. Inter., 35: 479 (1974).

49. Wilson, G. B., and Fudenberg, H. H.: Unpublished observations (1975).

50. Wilson, G. B., Fudenberg, H. H., and Jahn, T. L.: Studies on cystic fibrosis using isoelectric focusing. I. An assay for detection of cystic fibrosis homozygotes and heterozygotes from serum. Pediat. Res., 9: 635 (1975).

51. Wilson, G. B , and Jahn, T. L.: Decreased rate of cytolysis of Colpidium striatum by cystic fibrosis serum. I. Bioassay and evidence for the possible involvement of a C/F factor-IgG complex. Life Sci., 15: 551 (1974).

52. Wilson, G. B., Jahn, T. L. and Fonseca, J. R.: Demonstration of serum protein differences in cystic fibrosis by isoelectric focusing in thin-layer polyacrylamide gels. Clin. Chim. Acta, 49: 79 (1973).

53. Editorial: Developments in cystic fibrosis research. Lancet, ii: 307 (1973)

54. Hyland Immunoplate Division, Travenol Laboratories Inc., Costa Mesa, Calif.

55. Amicon Corp., Lexington, Mass.

56. LKB Produkter, A. B. Stockholm, Brooma, Sweden.

57. The authors gratefully acknowledge the assistance of Birt Harvey, M.D., Susan McHenry, Dan Stites, M.D., and John Whalen, M.D., in obtaining the blood samples used in this investigation.

58. Dr. G. B. Wilson was a Postdoctoral Research Fellow of the Cystic Fibrosis Research Foundation during the course of this investigation.

59. This research was supported in part by United States Public Health Service Grant HD-05894; by a grant from the Cystic Fibrosis Research Foundation; and by National Institutes of Health Grant AJ-09145.

60. This is paper number 18 from the Department of Basic and Clinical Immunology and Microbiology of the Medical University of South Carolina, Charleston, South Carolina (USA).

61. Requests for reprints should be addressed to: G. B. Wilson, Ph.D., Department of Clinical Immunology and Microbiology, Medical University of South Carolina, Charleston, S. C. 29401 (USA).

62. Accepted for publication September 16, 1975. 